\title{
FEATURES OF FUNDAMENTAL RIGHTS IN THE CONTEXT OF THE PHILOSOPHY OF LAW
}

\begin{abstract}
The article explores the notion and peculiarities of fundamental rights of the individual in the modern, legal state. In this research, the author implements versatile, holistic, systematical (methodical) analysis of content and distinguishing features of the structural elements of the concept "legal status of the individual". Therefore, the theoretical and practical research of problems of development of fundamental human rights gives an opportunity to find new solutions in protections of relations concerning the individual's legal status.

This study is also focusing on various approaches of well-known jurists on the essence, content and legislative consolidation of the fundamental rights of the individual.

The author comes to a conclusion that in recent decades, the philosophy of law (with the theory of state and law) took under its active protection and guardianship man with his rights, freedoms and legitimate interests, and which have ceased to be the subject of national legislation's regulation, and moved to the international legal platform. Consequently, the government is obligated to guarantee fundamental human rights and freedoms. Hence, theoretical, methodological and practical analysis of problems of the individual's legal status and elaboration of suggestions concerning the enhancement of national legislation, is one of the most actual problems of jurisprudence.
\end{abstract}

Keywords: fundamental human rights and freedoms, the legal status of the individual, legitimate interests, globalization, duties, citizen, democratic state, government.

A democratic, legal, and social state is a form of human coexistence where there are mutually agreed human relations, where the state and society assume a mutual obligation to help those in need, to influence the distribution of material goods, based on such principles of justice that guarantees of a decent life are created for everyone, as well as rights, freedoms and legitimate interests are protected (Harutyunyan, 2005, pp. 110-112; Yeritsyan, 2007, pp. 106-108). Consequently, the study and clarification of the concepts of human rights and fundamental free- doms, which are at the core of a person's legal status, are at the heart of the theory of modern philosophy of law (Huymens, 1995). Moreover, it is necessary to conduct a comprehensive study of the essence and content of rights, freedoms, legitimate interests of the individual in a modern democratic state. The system of rights, freedoms, legitimate interests and obligations that form the core of a person's legal status, as well as guarantees of their protection, is based on the fundamental principle of values, according to which a person is the highest value in the Repub- 
lic of Armenia. Moreover, the inalienable dignity of a person is an integral basis of his or her rights and freedoms.

The legal status of a person includes a combination of the rights, freedoms, duties and legitimate interests of the person, which, in turn, is a means of legal regulation that regulates the social status (position) of the person.

It is noteworthy that some of the modern legal scholars consider rights, freedoms and obligations as the main elements of the legal status of a person, and legitimate interests as additional (or derivative) ones (Rideau, 2003, pp. 23-24; Vitruk, 2008, p. 105).

In our opinion, this division of rights, freedoms, and duties has contributed to the humiliation of the essence of legitimate interests, as well as their important role in law, as a result of which this concept continues to be poorly studied in the legal literature. Based on the above, we propose to consider the rights, freedoms, duties and legitimate interests of the individual as the main elements of the legal status of the individual in the context of the philosophy of law.

\section{Analysis of the Fundamental Rights and Freedoms of the Individual}

It is obvious, that in the states which stand in the way of democracy, the rights and freedoms of the individual are not stationary and eternal, but are constantly changing and developing concepts (Marchenko, 2014, pp. 204-206; Trion, 2012, pp. 105-107). In addition, the basic rights and freedoms of the individual are not assigned by the state, since they do not exist because of formal consolidation, which is also very important, but because of the social capabilities of the person arising from the system of social relations. Furthermore, the source of individual rights and freedoms in a democratic society are real social relations, not the will of the legislator.

The conducted research shows that the social capabilities of the individual are social prerequisites for the formation, the regularity of development and the ability to use the advantages of legal rights, freedoms, legitimate interests, as well as the real content of duties. Therefore, a person's rights and freedoms are the social opportunities of the person enshrined in the law to possess certain goods to meet his or her needs. Moreover, legal rights and freedoms of a person acquire clear boundaries as a result of the state's implementation of legal regulation, and violation of these boundaries by a person is considered as illegal behaviour. In this case, of course, the legislator only considers the social opportunities to meet the needs of mankind, which, by stipulating in the norms of coexistence of public life, formally acquire the opportunity to be called human rights. Moreover, ideas about human rights, penetrating into the human masses, turn into a powerful material force, and for the state there is a need to fix the list of human rights determined by historical development in the law, that is, to establish the rights of a citizen as the legal rights of a person.

The idea of human rights also has a substantive basis, which was studied by K. Marx and F. Engels. They, considering man as a "result of history" and simultaneously leading the political and civil life of the subject, define the natural rights of the individual as historically formed bourgeois-democratic rights and freedoms, where the individual and the citizen are private owners (Marx \& Engels, 1955, pp. 390-391)

Taking the above idea as a basis, as well as the analysis of the material justification of human rights and social content, many soviet lawyers, such as I. Farber and G. Malcev (1969) be- 
gan to distinguish basic human rights from the rights of a citizen (pp. 26-27).

According to P. Nedbaylo (1965), the socio-political preconditions formed in the state and society are crucial to the formation of legally recognized, inalienable rights and freedoms of a person.. In this context, L. Voevodin (1997) rightly points out, that the real content of human rights as a socially conditioned opportunity, which in its essence is a requirement for the possession of certain social benefits (p. 115).

Meanwhile, V. Kartashkin (2018) proposes to distinguish the fundamental rights and duties of citizens (social category) from constitutional rights and responsibilities (legal category) (pp. 48-49). Based on the conducted research, we consider, V. Kartashkin's that approach to fundamental rights is exaggerated and may complicate the process of defining, examining the substance, content and elements of a person's legal status. Moreover, these opportunities for the person exist before their legislative confirmation.

According to the universally recognized definition, human rights are an opportunity to determine the extent of one's own behaviour. All other persons, public authorities, organizations must refrain from interfering with this behaviour (Ayvazyan, 2008, p. 12).

At the same time, various definitions and comments on fundamental human rights and freedoms can only be accepted partially and with certain reservations, since they generally do not fully reflect the essence and content of this concept, for example, according to Yu. Troshkin (1998), the fundamental rights are only those rights that are enshrined in the Constitution and the most important human rights documents, define the ideals of humanism in society, limit the power and protect people from their arbitrariness (pp. 30-31). Therefore, this definition is narrow in content, since it does not fully disclose the essence and meaning of fundamental rights.

Moreover, studies have shown that, due to modern political and legal processes, individual rights and freedoms are gradually becoming a standard for the development of society, the establishment of the idea of the rule of law and a stable factor in international legal cooperation.

In the modern world, the category of universal (fundamental) rights of the individual has been formed in the context of the universal equality of people, which has a common, generally accepted and legal meaning for the world community (Loth, 1998, pp. 22-24).

It is obvious that human rights and freedoms have ceased to be an object of domestic policy and practice of the state, and have become a problem of the entire international community.

Nowadays, the scope of individual rights and freedoms is determined not only by the specific characteristics of a particular society but also by the development of the civilization of all mankind, as well as the degree and level of integration into the international community of a given state. Therefore, fundamental rights become a high level in the international legal plane, below which any state, claiming to be a democratic, legal and social state, cannot descend. It is undeniable that a new phase in the history of human rights began after World War II when the processes of cooperation and integration of states developed and human rights gained universal recognition through international joint affairs. Thus, the UN General Assembly adopted the Universal Declaration of human rights (10.12.1948), which became the first-ever international universal document on the list of human rights and fundamental freedoms.

Thus, human rights are basic (fundamental) rights that are universal (extend to all who be- 
long to the biological type of Homo sapiens) and which are egalitarian (all are equal), as well as ensure a dignified life and development of the person in the context of the achievements of modern historical-social progress (Ebzeev, Aybazov, \& Krasnoryadtsev, 2006, pp. 54-57).

Considering a modern democratic, legal, social state, it becomes obvious that the priority of norms and principles of the internationally recognized human rights law in relation to domestic norms and principles is a categorical imperative of the international community.

At the same time, we agree with the opinion formed in recent years in the judicial literature and philosophy of law that the process of globalization cannot be the reason for the universalization of human rights, because the right to preserve the native language, culture, customs is the natural, inalienable right of every nation, ethnicity (Vencent 1989, pp. 49-54).

In our opinion, human rights and freedoms must correspond to the needs of a particular society and can have multiple forms of expression.

H. Behruz and M. Monshipouri rightly pointed out, that only those individual rights that correspond to the social problems of the society take into account cultural characteristics, religious traditions and beliefs, the accumulated experience of previous generations, and the moral principles of society can be recognized as universal rights (Behruz, 2006, pp. 20-22; Monshipouri, 1994). Consequently, there are objective justifications for both doubts and opposition to the universal nature of fundamental human rights.

First of all, there are regional, civilizational, and cultural differences in which people are born, raised, act, and think (Islamic, Jewish, etc.).

Second, there is a significant difference in the social conditions where people live in differ- ent countries, regions and continents.

Third, mutual disrespect for national and religious values in immigration processes.

It is hard to agree with the opinion of several modern researchers that the list of human rights and freedoms enshrined in a number of declarations on fundamental human rights and freedoms including the Universal Declaration of Human Rights (1948), the European Convention for the Protection of Human Rights and Fundamental Freedoms (1950), International Covenant on Civil and Political Rights (1966), is based solely on European values (Mutua, 2002, pp. 8283; Mattelman, 1996, p. 110). It is no coincidence that regional acts such as the American Convention on Human Rights (1969), the African Charter on Human and People Rights (1981), the Arab Charter of Human Rights (1994) are anchored not only on Universal Declaration of Human Rights but also on other human rights acts. Definitely, the organizations, which adopt those documents, take into consideration cultural characteristics and do not exclude other interpretations of international human rights norms. Actually, in all cases, there are even fundamental differences between the principles and reality proclaimed in international legal and regional instruments. For example, the status of women in Islamic countries, "inviolable" in India.

Therefore, progress is realized in any cultural civilization, in the process of gradual convergence of perception and implementation of the fundamental principles of human rights and, of course, is facilitated by the globalization of economic and law, immigration, exchange of cultural values, solution of global problems related to drug trafficking and the fight against international terrorism, natural and man-made disasters. 
In our opinion, there should be progress on the path of social and humanistic development and not the destruction of traditional values and the fall into prehistoric society.

On this issue, E. Lukasheva (2006) noted that the artificial acceleration of the process of adoption of international human rights norms, which contradicts the political, customary, cultural ideas of individual countries, regions is impermissible.

Therefore, we consider that it is necessary to respect a different world order and not try to change it through universal democratic and forcible implementation of human rights standards. It is important to have a constant dialogue of civilizations, a gradual and long-lasting process of perception, and adaptation to generally accepted norms and values, which opens the way to preserving the diversity and richness of the world.

It is known that those rights and freedoms that are more vital for the individual, society, and the government are enshrined in the Constitution and are called "basic rights and freedoms".

For example, Chapter 2 of the Constitution of Republic of Armenia: "Basic Rights and freedoms of the Human Being and the Citizen" includes such fundamental rights and freedoms of persons living in the territory of RA as the right to life, right to physical and mental integrity, the right to inviolability of the home, freedom of thought, conscience and religion, freedom of expression of opinion, right to judicial protection and the right to apply to international bodies for the protection of human rights etc. In addition, in Armenia, basic rights and freedoms of the human being and the citizen are regulated by other branches of law, which are not considered fundamental in their content, and therefore do not receive constitutional protection. Furthermore, rights enshrined in the current legislation specify, supplement and develop constitutional rights, which are based on the latter, and thus don't diminish the significance of constitutional rights and freedoms, their direct effect. For example, on the basis of these constitutional norms, the Criminal Code of RA contains many norms regarding sanctions provided for violations of the basic rights and freedoms of citizens. Moreover, according to article 81 of the Constitution of RA, the practice of bodies operating on the basis of international treaties on human rights, ratified by the Republic of Armenia, shall be taken into account when interpreting the provisions concerning basic rights and freedoms enshrined in the Constitution.

This leads to the conclusion that sectoral rights Supplement constitutional rights also for the reason that the latter are designed to fully cover the legal capacity of the individual in all spheres of various social relations, are independent and run parallel to the constitutional rights.

Consequently, branch rights supplement constitutional rights also because they are meant to fully cover a person's legal capacity in all areas of social relations, are progressing in parallel and independently of constitutional rights.

In other words, the ratio is not a ratio of whole and part, since both the basic and the rights established by the rules of the branches of law are independent. The correlation between these two groups of rights is that basic rights determine the content and main role not only of a particular right but also of the entire human rights system. Basic rights are rights that belong not to a particular group of people, but to each person. Therefore, we can say with confidence that basic rights are not only constitutional but also subjective rights. 


\section{Conclusions}

Summing up the results of explored issues and considering the fundamental rights as a dynamic phenomenon of the philosophy of law, we conclude that it is necessary to consider the rights of the individual, based on the combination of social conditions in this society and the state and the legal norms built on their basis. Social opportunities for a person enshrined by the state in the Constitution and laws become legal requirements that are subject to the protection (guarantee) of the state. Moreover, human rights are an opportunity to determine the extent of one's own behaviour. As a result of our research, we have come to the simple conclusion, that if a specific fundamental human right is not enshrined in the Constitution of a state, then it must be recognized in that state, regardless of its constitutional provision.

It is obvious that basic human rights are the inalienable, socially necessary opportunities guaranteed by the government, to freely, consciously and responsibly possess the vital material and spiritual goods.

\section{REFERENCES}

Ayvazyan, V. (2008). Mardu iravunqner (Human Rights, in Armenian). Yerevan: Tigran Mets.

Behruz, H. (2006). Evolyutsiya islamskogo prava: teoretiko-sravnitel'noe issledovanie (The Evolution of Islamic Law: a Theoretical and Comparative Study, in Russian). (PhD dissertation). Odessa.

Ebzeev, B., Aybazov, R., \& Krasnoryadtsev, S. (2006). Globalizatsiya i gosudarstvennoe edinstvo Rossii (Globalization and
State Unity of Russia, in Russian). Moscow: Formula prava.

Farber, I. (1967). Prava cheloveka, grazhdanina i litsa v sotsialisticheskom obshchestve (Human Rights, Citizen and Person in a Socialist Society, in Russian). Jurisprudence, 1, 39-46.

Harutyunyan, G. (2005). Sahmanadrakan mshakuyt. Patmutyan dasery yev zhamanaki martahravernery (Constitutional Culture: the Lessons of the History and the Challenges of the Time, in Armenian). Yerevan: Nzhar Publishing.

Huymens, J. (1995). Post-Cold War Imposion and Globalisation: Liberalism Runnig Past Itself. Millennium: Journal of International Studies, 24(3), 88-87.

Kartashkin, V. (2018). Prava cheloveka: mezhdunarodnaya zashchita $v$ usloviyakh globalizatsii (Human rights: international protection in the context of globalization, in Russian). Moscow: Norma.

Loth, W. (1998). The Division of the World 1941-1945. London: Routledge.

Lukasheva, E. (2006). Prava cheloveka. Konflikt kultur (Human Rights. The Conflict of Cultures, in Russian). Russian justice. 6, 15-24.

Malcev, G. (1969). Sotsialisticheskoye pravo $i$ svoboda lichnosti (teoreticheskiye voprosy). (Socialist Law and Personal Freedom (Theoretical Issues), in Russian). Moscow: Yuridicheskaya literatura.

Marchenko, M. (2014). Teoriya gosudarstva $i$ prava. (Theory of State and Law, in English) (3rd ed.). Moscow: Yurayt.

Marx, K., \& Engels, F. (1955). Sochineniya (Works, in Russian) (2nd ed., Vol. 1). 
Moscow: State Publishing House.

Mattelman, J. (1996). Globalization: Critical Reflactions. New York: Lynne Rienner pub. Boulder.

Monshipouri, M. (1994). Islamic Thinking and the Internationalization of Human Rights. The Muslim World, LXXXIV, 217-239.

Mutua, M. (2002). Human Rights: A Political and Cultural Critique. Philadelphia: Philadelphia Univ. Press.

Nedbaylo, P. (1965). Aktual'nye voprosy sovetskoi yuridicheskoi nauki (Actual Issues of Soviet Legal Science, in Russian). Abstracts of the Republican Interuniversity Scientific Conference Dedicated to the Problems of Soviet Law (p. 5). Odessa: Publishing house of the State University I.I. Mechnikov.

Rideau, J. (2003). Droit institutionnel de l'Union et des Communautes Europeennes. 4ème éd.. Paris: L.G.D.J.

Trion, N. (2012). Théorie générale du droit:
Droit, pouvoire, savoir. 2ème éd. Paris: Lancier.

Troshkin, Y. (1998). Prava cheloveka (Human Rights, in Russian). Moscow: Polygraphouse of Administration of Moscow reg.

Vencent, R. (1989). Human Rights and Iternational Relations. Cambridge: CUP.

Vitruk, V. (2008). Obshchaya teoriya pravovogo polozheniya lichnosti. (The General Theory of the Legal Status of a Person, in Russian). Moscow: Norma.

Voevodin, L. (1997). Yuridicheskiy status lichnosti $v$ Rossii (The Legal Status of a Person in Russia, in Russian). Moscow: Norma.

Yeritsyan, A. (2007). Mardu iravunqneri yev drants pashtpanut'yan himnakhndirnery globalizatsiayi darashrjanum (Problems of Human Rights and their Protection in the Age of Globalization, in Armenian). Yerevan: Heghinakayin hratarakchutyun. 